\title{
Early beta cell dysfunction vs insulin hypersecretion as the primary event in the pathogenesis of dysglycaemia
}

\author{
Nathalie Esser ${ }^{1,2}$ (D) $\cdot$ Kristina M. Utzschneider ${ }^{1,2}$ (D) Steven E. Kahn ${ }^{1,2}$ (i)
}

Received: 20 April 2020 / Accepted: 7 July 2020 / Published online: 31 August 2020

(C) This is a U.S. government work and not under copyright protection in the U.S.; foreign copyright protection may apply 2020

\begin{abstract}
Obesity and insulin resistance are associated with the development of type 2 diabetes. It is well accepted that beta cell dysfunction is required for hyperglycaemia to occur. The prevailing view is that, in the presence of insulin resistance, beta cell dysfunction that occurs early in the course of the disease process is the critical abnormality. An alternative model has been proposed in which primary beta cell overstimulation results in insulin hypersecretion that then leads to the development of obesity and insulin resistance, and ultimately to beta cell exhaustion. In this review, data from preclinical and clinical studies, including intervention studies, are discussed in the context of these models. The preponderance of the data supports the view that an early beta cell functional defect is the more likely mechanism underlying the pathogenesis of hyperglycaemia in the majority of individuals who develop type 2 diabetes.
\end{abstract}

Keywords Beta cell function $\cdot$ Hyperinsulinaemia $\cdot$ Insulin resistance $\cdot$ Obesity $\cdot$ Prediabetes $\cdot$ Review $\cdot$ Type 2 diabetes

$\begin{array}{ll}\text { Abbreviations } \\ \text { DPP-4 } & \text { Dipeptidyl peptidase-4 } \\ \text { GLP-1R } & \text { Glucagon-like peptide-1 receptor } \\ \text { HFD } & \text { High-fat diet } \\ \text { IFG } & \text { Impaired fasting glucose } \\ \text { IGT } & \text { Impaired glucose tolerance }\end{array}$

\section{The beta cell in type 2 diabetes: history of the debate}

Type 2 diabetes is characterised by hyperglycaemia, typically due to the interaction of insulin resistance and impaired beta cell function [1]. The relative importance of these two critical factors has been extensively debated [2-8].

Electronic supplementary material The online version of this article (https://doi.org/10.1007/s00125-020-05245-x) contains a slideset of the figures for download, which is available to authorised users.

Steven E. Kahn

skahn@uw.edu

1 Veterans Affairs Puget Sound Health Care System, 1660 South Columbian Way (151), Seattle, WA 98108, USA

2 Division of Metabolism, Endocrinology and Nutrition, Department of Medicine, University of Washington, Seattle, WA, USA
Four decades ago, many felt insulin resistance was the primary abnormality in type 2 diabetes, with beta cell dysfunction being a later manifestation, when beta cells were no longer able to sustain sufficient insulin secretion to compensate and became 'exhausted' [2-5]. In contrast, others postulated that beta cell dysfunction was an early prerequisite for the development of dysglycaemia [6-8]. Currently, the predominantly accepted view is that beta cell dysfunction, manifest as impaired insulin secretion, is a primary independent abnormality that typically occurs early in the pathogenesis of dysglycaemia, on a background of insulin resistance (Fig. 1a).

Recently, an alternative view that posits that primary hypersecretion of insulin is the initial manifestation of beta cell dysfunction has regained attention. This concept hypothesises that beta cell overstimulation in a hostile environment is primary and the resultant hyperinsulinaemia initiates and sustains the development of obesity and insulin resistance until, ultimately, the beta cell fails [9-14] (Fig. 1b). In this model, insulin resistance is considered an adaptive response to protect against energy-induced metabolic stress, rather than being the cause of hyperinsulinaemia.

In this review, we address these two beta cell-based hypotheses by discussing insights gained from preclinical and human studies. Further, we examine recent lessons learned from direct comparisons of youths and adults. 
Fig. 1 Models of primary beta cell dysfunction and primary insulin hypersecretion in the pathogenesis of type 2 diabetes. (a) In the first model, the interaction of environmental factors with obesity and insulin resistance genes leads to the development of abdominal obesity and insulin resistance. This results in increased secretory demand on beta cells, which adapt by producing compensatory hyperinsulinaemia to maintain normal glucose tolerance. In contrast, in the presence of an early beta cell defect caused by genetics and environmental factors, the increased beta cell secretory demand leads to relative hypoinsulinaemia and the development of dysglycaemia and, ultimately, type 2 diabetes. (b) In the second model, beta cell overstimulation, which may be genetic or linked to

environmental factors, leads to hyperinsulinaemia and this, in turn, produces obesity and insulin resistance. Type 2 diabetes ultimately develops when beta cell exhaustion occurs. The important early stages in each of the hypotheses are shown in bold font. This figure is available as part of a downloadable slideset

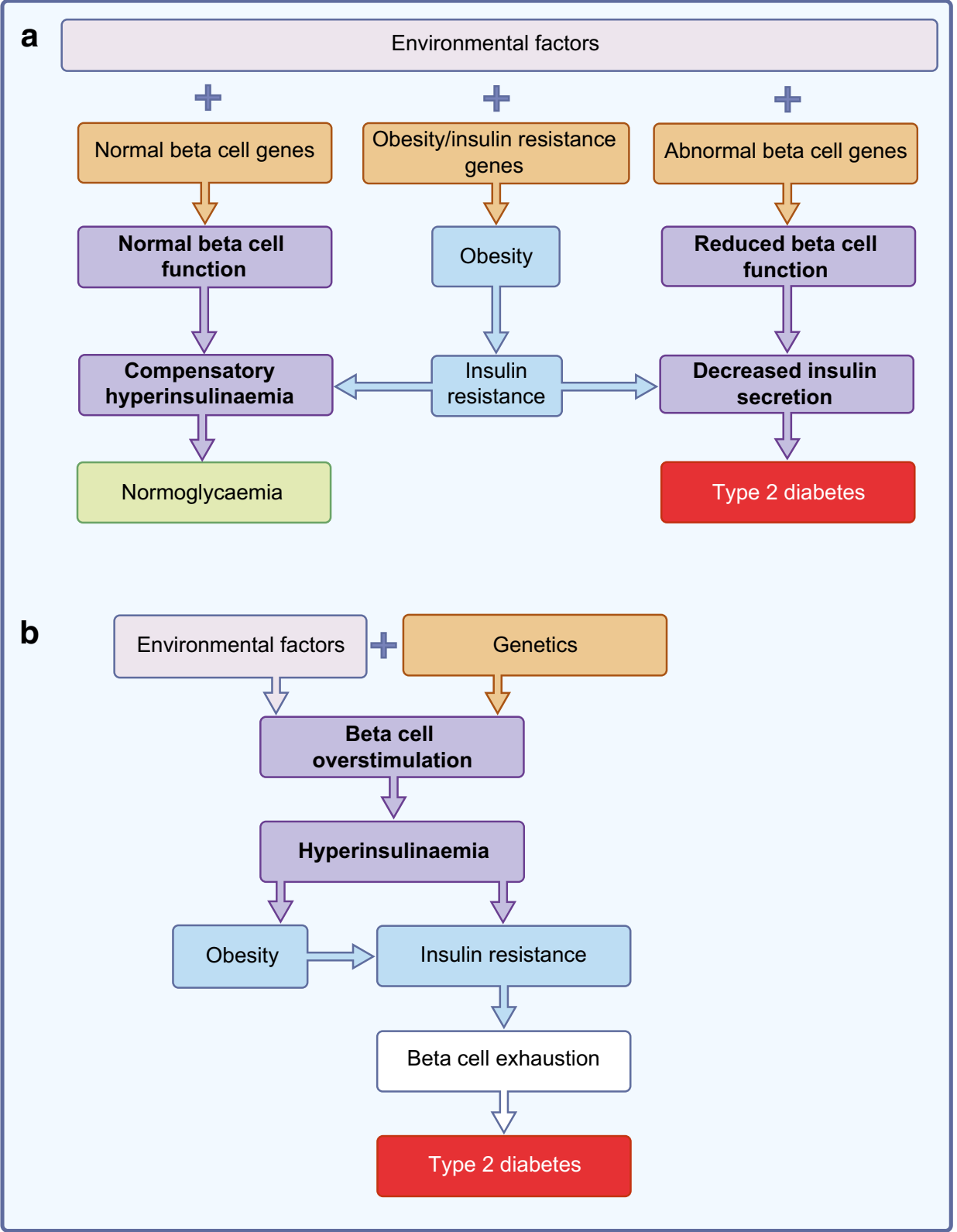

\section{Crosstalk between the beta cell and insulin-sensitive tissues}

Homeostatic control in endocrinology is intimately tied to feedback loops, and glucose metabolism is no different. Below we consider, with the two aforementioned hypotheses in mind, the interaction between the beta cell and insulinsensitive tissues (liver, adipose tissue, muscle) under conditions of normal glucose homeostasis.

In a model where insulin secretion is modulated by insulin sensitivity, the former will increase or decrease reciprocally with changes in insulin sensitivity, thereby maintaining normal glucose tolerance. In the presence of obesity and insulin resistance, the beta cell adapts by increasing insulin output, leading to peripheral compensatory hyperinsulinaemia (Fig. 2a).

In a model that presupposes beta cell hypersecretion as the initial manifestation of beta cell dysfunction, insulin sensitivity is modulated by insulin secretion. When beta cell hypersecretion occurs, the responsiveness of insulin-sensitive tissues to insulin is downregulated and these tissues become insulin resistant in order to maintain normal glucose tolerance without the adverse outcome of hypoglycaemia (Fig. 2b). However, as the beta cell hypersecretion is primary and 'fixed', when insulin sensitivity is acutely improved, hypoglycaemia would be expected to ensue.

In either case, the demonstration of the existence of a feedback loop that regulates glucose metabolism has made it 
a

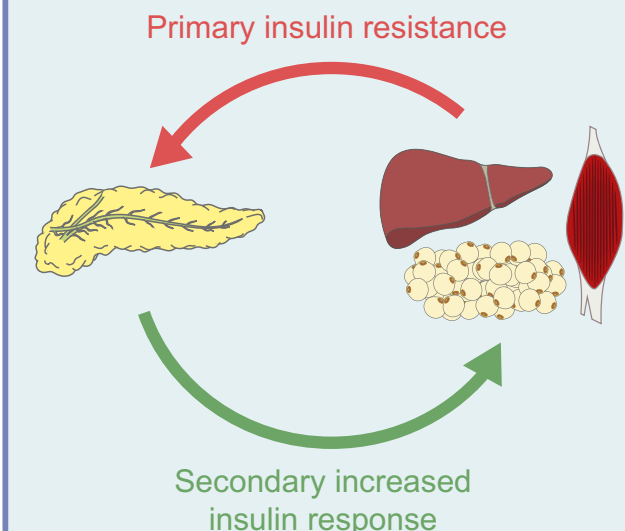

b

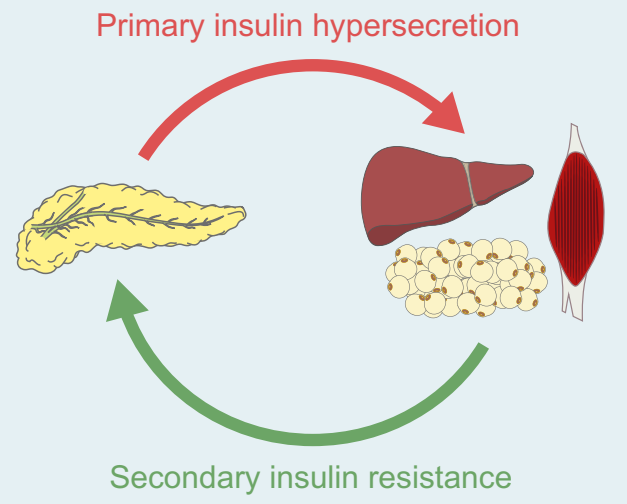

Fig. 2 Crosstalk between the beta cell and insulin-sensitive tissues. (a) Model in which the degree of insulin sensitivity in the peripheral tissues (liver, adipose tissue and muscle) is the principal determinant of the magnitude of the beta cell response. With the development of obesity and insulin resistance (primary insulin resistance), the beta cells in the pancreas compensate by increasing the insulin response (secondary increased insulin response), thereby avoiding the development of

abundantly clear that assessment of the adequacy of beta cell function requires knowledge of both the degree of insulin sensitivity and the magnitude of the insulin response [15].

\section{The case for primary early beta cell dysfunction in the pathogenesis of dysglycaemia}

Use of the disposition index, a measure of beta cell function that accounts for the degree of insulin sensitivity, has highlighted that, when the feedback loop becomes deranged due to beta cell dysfunction, dysglycaemia ensues [15]. Both cross-sectional and longitudinal studies have demonstrated that beta cell dysfunction is already present early in the natural history of dysglycaemia, with progressive dysfunction ultimately leading to diagnostic hyperglycaemia [7, 16-21]. This has been shown to occur in populations that phenotypically are not usually considered obese, e.g. Japanese Americans and Asian Indians [19, 21], and others, such as the Pima Indians, who were previously thought to have a disease process driven by insulin resistance [16]. The critical role of an early beta cell functional defect in type 2 diabetes is further highlighted by the observations of reduced beta cell function in groups at increased risk of developing type 2 diabetes, including normoglycaemic first-degree relatives of individuals with type 2 diabetes [22-24], and women with polycystic ovary syndrome [25] or history of gestational diabetes [26, 27]. hyperglycaemia. (b) Model in which the amount of insulin secreted determines the degree of insulin sensitivity in the peripheral tissues. In response to primary insulin hypersecretion by the beta cells, insulin-sensitive tissues decrease their sensitivity to insulin (secondary insulin resistance), thereby preventing the development of chronic hypoglycaemia. This figure is available as part of a downloadable slideset

We have re-examined our data in a Japanese American cohort living in Seattle, WA, USA to determine insulin sensitivity and beta cell function across the spectrum of fasting glucose in this high-risk population [28]. Increasing fasting glucose concentrations were associated with significant increases in fasting insulin (Fig. 3a, b) and decreases in insulin sensitivity (Fig. 3c, d). The stimulated insulin response to oral glucose was lower in individuals with dysglycaemia (Fig. 3e, f). Further, the disposition index, which accounts for differences in insulin sensitivity, showed beta cell function to be reduced by $\sim 40 \%$ in individuals with impaired fasting glucose (IFG) and $>80 \%$ in those with type 2 diabetes (Fig. 3g, h). This degree of beta cell dysfunction is more in line with that reported for type 1 diabetes [29] and what is generally accepted for endocrine systems before a clinical phenotype develops. Of note, beta cell function decreased as fasting glucose levels increased (Fig. 3h; $p<0.0001$ ), with no evidence of early insulin hypersecretion or insulin resistance in those with the lower glucose levels (Fig. 3b, d). To ensure that these observations were not unique to Japanese American individuals, we re-examined data from the Genetics of NonInsulin-Dependent Diabetes (GENNID) cohort [30] and found the same pattern for white, African-American and Latino individuals (N. Esser and S. E. Kahn, unpublished data). These observations are in keeping with those in other cohorts [20, 31, 32]. Further, the critical importance of reduced beta cell responses was highlighted by their strong predictive power for the subsequent development of dysglycaemia [19, 33, 34], which was better than that of fasting insulin [19]. 

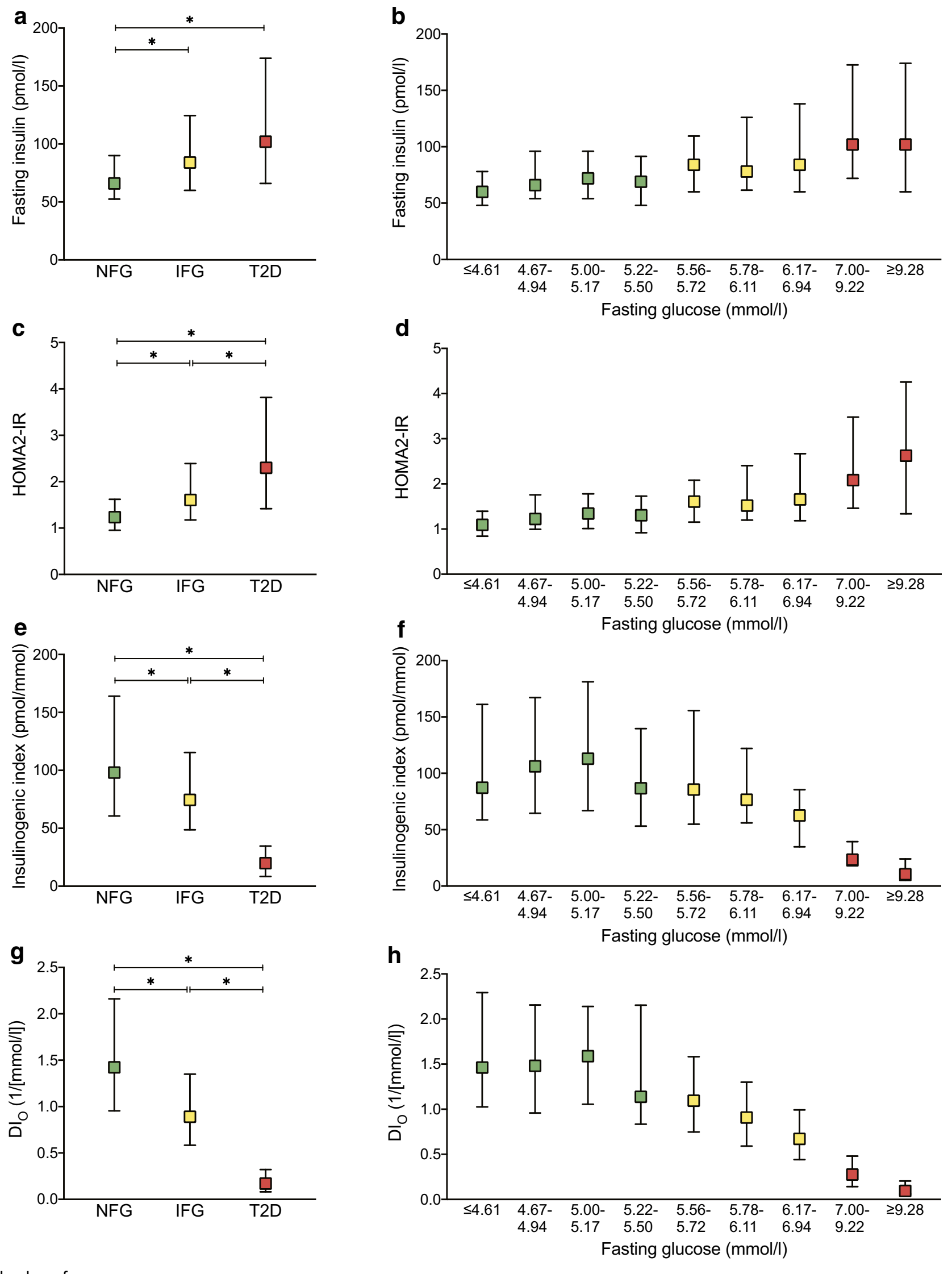

$\begin{array}{llll}\begin{array}{l}\text { Number of } \\ \text { individuals: }\end{array} & 374 & 168 & 71\end{array}$

$\begin{array}{lllllllll}80 & 113 & 71 & 110 & 62 & 56 & 50 & 36 & 35\end{array}$ 
Fig. 3 Insulin sensitivity and beta cell response across ranges of fasting glucose. Relationship of fasting glucose with $(\mathbf{a}, \mathbf{b})$ fasting insulin, $(\mathbf{c}, \mathbf{d})$ insulin sensitivity quantified by the HOMA2-IR, $(\mathbf{e}, \mathbf{f})$ the insulinogenic index, and $(\mathbf{g}, \mathbf{h})$ beta cell function quantified as the oral disposition index $\left(\mathrm{DI}_{\mathrm{O}}\right)$, in 613 Japanese American individuals. HOMA2-IR was calculated from fasting glucose and insulin levels using the HOMA2 calculator (www.dtu.ox.ac.uk/homacalculator/; accessed 19 May 2020) [110]. The insulinogenic index and $\mathrm{DI}_{\mathrm{O}}$ were calculated as $\Delta \mathrm{I}_{0-30} / \Delta \mathrm{G}_{0-30}$ and $\Delta \mathrm{I}_{0-}$ ${ }_{30} / \Delta \mathrm{G}_{0-30} \times 1 /$ fasting insulin, respectively, where $\Delta \mathrm{I}_{0-30}$ is the change in insulin concentration and $\Delta \mathrm{G}_{0-30}$ is the change in glucose concentration between 0 and 30 min during an OGTT, as previously described [19]. Data are reported as median and IQR. The 2003 American Diabetes Association criteria were used to categorise participants as having normal fasting glucose (NFG; green squares; $n=374$ ), IFG (yellow squares; $n=168$ ) or type 2 diabetes (T2D; red squares; $n=71$ ). The $n$ values in (g) also apply to (a), (c) and (e), while those in (h) also apply to (b), (d) and (f). ${ }^{*} p<0.05$ based on Kruskal-Wallis with Dunn's multiple comparisons tests. Figure based on data in [19]. This figure is available as part of a downloadable slideset

\section{The case for insulin hypersecretion in the pathogenesis of dysglycaemia}

The prevailing view that the hyperinsulinaemia of obesity is a compensatory response of the beta cell to increased insulin resistance has been challenged by several groups [9-14]. It is proposed that environmental changes, such as chronic excess of nutrients [12], food additives [11] or diabetogenic signals from the gut [10], result in beta cell overstimulation, exhibited as basal hyperinsulinaemia. The result is the development of obesity and insulin resistance, with these processes occurring either in series or in parallel. Based on this hypothesis, primary hyperinsulinaemia is the culprit that ultimately leads to beta cell exhaustion, manifest as reduced insulin secretion.

When considering the feedback loop governing glucose metabolism, in the face of increased insulin secretion, insulin resistance should develop as a protective measure to maintain normal glucose concentrations without hypoglycaemia. This is supported by observations in patients with insulinomas in whom the danger of hypoglycaemia is reduced by downregulation of insulin action through the development of insulin resistance [35-37]. Further support for this downregulation of insulin action comes from studies in healthy individuals with normal glucose tolerance in whom insulin resistance developed during 3-5 days of chronic physiological hyperinsulinaemia, which was achieved by insulin infusion balanced by glucose infusion to prevent hypoglycaemia [38].

Increased basal insulin concentrations have been documented in individuals with obesity and impaired glucose tolerance (IGT) before the development of type 2 diabetes and identified as a risk factor for diabetes [39-41]. However, these studies frequently do not account for differences in the prevailing glucose concentration and insulin sensitivity, two important drivers of fasting insulin concentrations. Two studies have accounted for these factors, in part; one found increased fasting insulin concentrations predicted type 2 diabetes development [42] and the other observed that insulin hypersecretion during an OGTT predicted subsequent dysglycaemia [43]. However, in the latter study, OGTT glucose levels were already higher in those who progressed and could be a confounder. Thus, these two studies provide some support for the concept of a potential independent pathogenic role of primary hyperinsulinaemia in dysglycaemia.

\section{Additional insights from interventional studies in animals and humans}

\section{Preclinical studies}

A genetic background linked to beta cell dysfunction appears to be required for the development of hyperglycaemia in dietinduced obese mice [44-46]. Mice fed a high-fat diet (HFD) commonly develop obesity, insulin resistance and hyperinsulinaemia, but susceptibility to hyperglycaemia in this setting varies by strain. For example, after a year on an HFD, C57BL/6J $\times$ DBA/2J mice develop obesity and hyperinsulinaemia and, if anything, have better glucose tolerance than mice fed a low-fat diet [47]. This may be due to the DBA/2 component of the hybrid mice, as such a background is associated with insulin hypersecretion without hyperglycaemia [44], while C57BL/6J mice do develop hyperglycaemia after 6 months on an HFD [48]. The importance of reduced insulin secretion in the pathogenesis of hyperglycaemia is further supported by a study in which young mice received low doses of the beta cell toxin streptozotocin, followed by high-fat feeding. This experimental paradigm resulted in hyperglycaemia and beta cell secretory defects, as observed in human type 2 diabetes [49].

Ablation of insulin action through either insulin receptor or glucose transporter disruption has highlighted that reducing insulin's effect alone does not necessarily lead to diabetes $[50,51]$. Doing so in muscle and fat led to decreased insulin-stimulated glucose transport and hyperinsulinaemia [51]. Deletion of the insulin receptor in muscle increased fat mass and resulted in hypertriacylglycerolaemia and elevated non-esterified fatty acids, without a change in glucose tolerance even at 20 months of age [52]. In the liver, $50 \%$ loss of the glucose transporter did not alter glucose tolerance, while complete deletion of the insulin receptor led to hyperglycaemia in young animals that resolved by 4 months of age, perhaps because of liver dysfunction [51,53]. Deletion of the insulin receptor in the brain resulted in hyperphagia followed by obesity, insulin resistance and hyperinsulinaemia, with no evidence of hyperglycaemia [54]. Only with loss of the insulin receptor in the beta cell did impaired glucose- 
induced insulin secretion and progressive post-glucose-load hyperglycaemia occur over time [55].

Insulin injection has been used as an experimental paradigm to induce hyperinsulinaemia. This approach led to hypoglycaemia and compensatory hyperphagia with resultant weight gain in rats, effects that dissipated after insulin resistance had developed to protect against hypoglycaemia [56-58]. In one of these studies, mild glucose intolerance was observed after 10 days of intervention, but beta cell function and glucose tolerance were not examined over a longer period [58]. Chronic hyperinsulinaemia has also been induced from conception by overexpression of the insulin gene in mice [9]. In this mouse model, insulin resistance developed secondary to hyperinsulinaemia, without a change in fasting glucose until 10-12 months of age, when these mice manifested glucose intolerance due to a delayed early insulin response [9]. However, against the predictions in the model favouring primary hyperinsulinaemia as the basis for the ultimate development of dysglycaemia, these mice did not become obese.

Built on the premise that hyperinsulinaemia is deleterious, recent mouse studies used the approach of reducing insulin production by deleting two or three insulin alleles. The prediction was that this would prevent hyperinsulinaemia and, thereby, weight gain, insulin resistance, glucose intolerance and dysglycaemia in mice fed an HFD for 1 year. Figure 4 illustrates the phenotypic differences in mice fed an HFD compared with their littermate controls on a moderate-fat diet. Only mice that were null for Ins 1 developed the expected phenotype of obesity, hyperinsulinaemia and insulin resistance; however, these mice did not develop diabetes as may have been expected [59,60] (Fig. 4a, b). Very little effect on this phenotype was observed when one of the Ins 2 alleles was also deleted, with no sex-based effect observed [59, 60] (Fig. $4 \mathrm{a}, \mathrm{b})$. The phenotype of the mice that were null for Ins $2 \mathrm{did}$ not differ in females on the two diets, whether they were homozygous or heterozygous for Ins 1 , while males lacking one Ins 1 allele did not develop obesity and insulin resistance [61] (Fig. 4c, d). Of note, these studies did not include mice with a full complement of (four) insulin alleles, so it is unclear whether the loss of two or three alleles even had an impact on the normal phenotype. The lack of this control group means that any potential compensatory change in response to gene deletion cannot be excluded [62] and it is unclear whether the presence of four insulin alleles would have been associated with hyperglycaemia. Thus, from these studies it is rather difficult to determine whether reducing insulin production by systematic insulin gene deletion produces a phenotype supporting primary hypersecretion as a pathological entity.

In summary, the preclinical literature supports the concept that an HFD results in obesity, insulin resistance and hyperinsulinaemia, but does not cause hyperglycaemia unless a genetic susceptibility to reduced beta cell function exists. Genetic induction of reduced peripheral insulin action or experimental hyperinsulinaemia alone do not produce diabetes. Attempts to reduce hyperinsulinaemia genetically were predicted to improve obesity and insulin sensitivity, but the outcomes were not consistent. Thus, it would appear that the only approaches that result in persistent hyperglycaemia are those in which a compensatory increase in insulin secretion cannot occur because of either a genetic or chemically induced beta cell defect.

\section{Human studies}

Interventional studies examining changes in body weight, insulin sensitivity and beta cell function provide valuable insight into understanding the mechanisms by which type 2 diabetes may occur.

If beta cell dysfunction is the primary driving factor in the pathogenesis of dysglycaemia (Fig. 1a), one would expect that weight loss and medical interventions targeting insulin resistance to be beneficial. This benefit would result from an 'offloading' of the dysfunctional beta cell leading to a reduction in glucose and insulin levels. The use of secretagogues would increase the workload on a dysfunctional beta cell, initially improving glucose levels but possibly leading to beta cell failure.

On the other hand, if hyperinsulinaemia is the primary driving factor and precedes obesity and insulin resistance (Fig. 1b), interventions that aim to directly reduce insulin hypersecretion should have a fairly rapid benefit on insulin sensitivity that should continue to improve as obesity resolves. With a rapid reduction in insulin secretion, unless a marked decrease in energy intake or improvement in insulinindependent glucose uptake were to occur, an increase in plasma glucose would be expected. Alternatively, if insulin resistance is downstream of insulin hypersecretion, primarily improving insulin sensitivity would not be expected to change insulin secretion and would be likely to result in ongoing hypoglycaemia. Such would be akin to the hypoglycaemia observed in people with type 1 diabetes on a fixed insulin dose, in whom acute exercise or reduced energy intake result in hypoglycaemia [63-66]. This hypoglycaemia could be obviated if counterregulatory responses are activated and remain permanently so unless either the beta cell eventually reduces its excessive output or the continued counterregulation in and of itself leads to insulin resistance. Finally, increasing insulin levels with secretagogues in an unregulated manner should produce insulin resistance, increase body weight, induce hypoglycaemia and, ultimately, precipitate beta cell failure.

Lifestyle Randomised studies of diabetes prevention have shown that lifestyle interventions effectively prevent progression from IGT to type 2 diabetes [67-69]. Two of these studies demonstrated that weight loss was associated with 


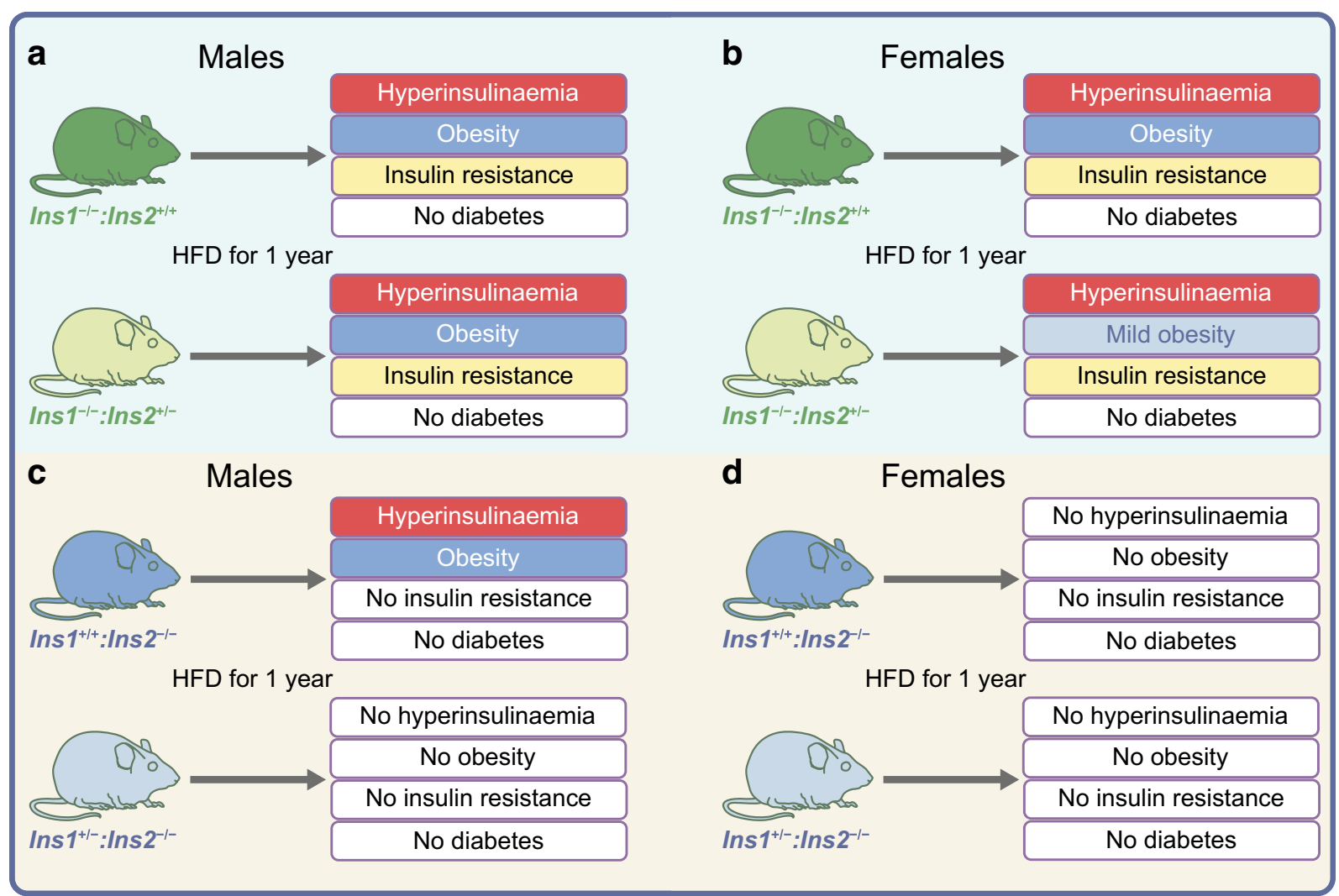

Fig. 4 Metabolic phenotypes of mice fed an HFD for 1 year when lacking two or three insulin gene alleles. Ins ${ }^{-/-}:$Ins $2^{+-}$(light green) and $I n s 1^{+-}$ :Ins $2^{--}$(light blue) mice (lacking three insulin alleles) and their littermate controls, Ins $1^{-/-}: I n s 2^{+/+}$(dark green) and $I n s 1^{+/+}: I n s 2^{-/-}$(dark blue) mice (lacking two insulin alleles) were fed an HFD (58\% energy from fat) for 1 year. The figure summarises the metabolic phenotype these mice developed at the end of the study with respect to plasma insulin levels, body weight gain, insulin resistance and hyperglycaemia/diabetes compared with identical mice fed a moderate-fat diet (25\% energy from fat). (a) Both $\operatorname{Ins}{1^{-/}}^{-1}$ Ins $2^{+/}$and $\operatorname{Ins}{1^{-/}}^{-/} \operatorname{Ins} 2^{+/+}$male mice developed HFD-induced hyperinsulinaemia, obesity and insulin resistance. In one cohort of male mice, Ins $1^{-/}$:Ins $2^{+/-}$mice developed a mild impairment of glucose disposal during an IPGTT compared with $\operatorname{Ins1^{-/}}: \operatorname{Ins} 2^{+/+}$ mice, but these findings were not reproduced in a second cohort (data from [60]). (b) HFD induced milder obesity in Ins $1^{-/-}$:Ins $2^{+/-}$female

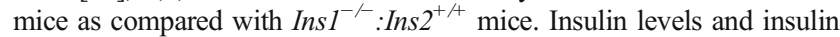
resistance were similar in both groups of mice after 1 year on the HFD. Neither genotype developed diabetes but both had mild impairments in glucose tolerance (data from [59]). (c) HFD-induced fasting hyperinsulinaemia and obesity did not occur in $\operatorname{Ins} 1^{+-}: \operatorname{Ins} 2^{-/-}$male mice but was observed in $I n s 1^{+/+}$:Ins $2^{-/-}$male mice. Neither genotype developed insulin resistance or hyperglycaemia (data from [61]). (d) Both Ins $1^{+/+}$:Ins $2^{-/}$and Ins $1^{+/}$:Ins $2^{-/-}$female mice fed an HFD did not develop hyperinsulinaemia, obesity, insulin resistance or hyperglycaemia (data from [61]). This figure is available as part of a downloadable slideset

Inhibition of insulin secretion: potassium channel openers and somatostatin analogues Studies using potassium channel openers have shown inconsistent results in humans (Table 1). With primary hyperinsulinaemia, the prediction would be an improvement in insulin sensitivity and decrease in body weight. In obese, non-diabetic, hyperinsulinaemic participants, when diazoxide (a potassium channel opener) was combined with a dietary intervention, three studies reported greater weight loss along with reduced insulin levels from baseline [72-74]. However, when compared with placebo, weight loss was only greater in two studies [72, 74], of which only one found a greater reduction in fasting insulin with diazoxide vs placebo [74]. Insulin sensitivity improved in one study with diazoxide use when compared with placebo [74], but not in the other two studies [72, 73]. While the studies lasted between 2 and 6 months, the reasons for the
Medications Various studies using therapeutic agents shed light on the primary beta cell dysfunction vs primary insulin hypersecretion hypotheses. Some of these studies are outlined below. 
Table 1 Study design, baseline characteristics and metabolic outcomes of double-blind, placebo-controlled, intervention studies with diazoxide

\begin{tabular}{|c|c|c|c|c|c|c|}
\hline $\begin{array}{l}\text { Inclusion criteria and mean baseline } \\
\text { characteristics }\end{array}$ & $N(\mathrm{~F} / \mathrm{M})$ & $\begin{array}{l}\text { Study } \\
\text { duration }\end{array}$ & Dose of diazoxide & Other intervention(s) & Outcomes vs placebo ${ }^{a}$ & Reference \\
\hline $\begin{array}{l}\text { Inclusion criteria: obese (BMI } \\
\geq 30 \mathrm{~kg} / \mathrm{m}^{2} \text { ), no diabetes (fasting } \\
\text { glucose }<6.67 \mathrm{mmol} / \mathrm{l} \text { and } / \mathrm{or} \\
\mathrm{HbA}_{1 \mathrm{c}}<53 \mathrm{mmol} / \mathrm{mol}[<7 \%] \text { ) } \\
\text { Baseline characteristics: BMI } \\
\quad 41.7 \mathrm{~kg} / \mathrm{m}^{2}, \text { fasting glucose } \\
5.3 \mathrm{mmol} / \mathrm{l}, \mathrm{HbA}_{\mathrm{lc}} 40 \mathrm{mmol} / \mathrm{mol} \\
{[5.8 \%], \text { fasting insulin } 186 \mathrm{pmol} / \mathrm{l}}\end{array}$ & $24(20 / 4)$ & 8 weeks & $\begin{array}{c}2 \mathrm{mg} \mathrm{kg}^{-1} \text { day }^{-1} \\
\text { (maximum } \\
200 \mathrm{mg} / \text { day) }\end{array}$ & $\begin{array}{l}\text { Low energy diet started } \\
1 \text { week before } \\
\text { diazoxide }\end{array}$ & $\begin{array}{l}\text { - No difference in fasting } \\
\text { insulin (reduced fasting } \\
\text { insulin on diazoxide } \\
\text { compared with } \\
\text { baseline) } \\
\text { - } \downarrow \text { GSIS (AIR } \text { Al }_{\mathrm{g}} \text { during } \\
\text { IVGTT) } \\
\text { - No difference in fasting } \\
\text { glucose and glucose } \\
\text { disposal }\left(\mathrm{K}_{\mathrm{G}} \text { ) }\right. \\
\text { - No difference in HbA } \mathrm{Hb}_{1 \mathrm{c}} \\
\text { levels } \\
\text { - No difference in insulin } \\
\text { sensitivity (Bergman's } \\
\text { minimal model) } \\
\text { - Body weight and body } \\
\text { fat } \\
\text { - No difference in REE }\end{array}$ & {$[72]$} \\
\hline $\begin{array}{l}\text { Inclusion criteria: overweight and } \\
\text { obese (BMI } 27-66 \mathrm{~kg} / \mathrm{m}^{2} \text { ), no } \\
\text { diabetes (fasting glucose } \\
<6.1 \mathrm{mmol} / \mathrm{l}), \text { hyperinsulinaemic } \\
\text { (fasting insulin } \geq 100 \mathrm{pmol} / \mathrm{l} \text { ) }\end{array}$ & $35(32 / 3)$ & 8 weeks & $\begin{array}{l}2 \underset{\mathrm{m} \mathrm{kg}^{-1} \text { day }^{-1}}{(\text { maximum }} \\
200 \mathrm{mg} / \text { day })\end{array}$ & $\begin{array}{l}\text { Fat-reduced, } \\
\text { energy-restricted } \\
\text { weight-loss diet } \\
\text { (2.5 MJ energy } \\
\text { deficient/day) }\end{array}$ & $\begin{array}{l}\text { - No difference in fasting } \\
\text { insulin (reduced fasting } \\
\text { insulin on diazoxide } \\
\text { compared with } \\
\text { baseline) }\end{array}$ & {$[73]$} \\
\hline $\begin{array}{l}\text { Baseline characteristics: BMI } \\
41.5 \mathrm{~kg} / \mathrm{m}^{2} \text {, fasting glucose } \\
5.99 \mathrm{mmol} / \mathrm{l} \text {, fasting insulin } \\
138 \mathrm{pmol} / \mathrm{l}\end{array}$ & & & & & $\begin{array}{l}\text { - } \downarrow \text { GSIS (iAUC } \text { ins during } \\
\text { OGTT and MTT) } \\
\text { - No change in fasting } \\
\text { glucose } \\
\text { • } \downarrow \text { Glucose tolerance } \\
\text { - No difference in insulin } \\
\text { sensitivity (Matsuda } \\
\text { index) } \\
\text { - No change in body } \\
\text { weight, body fat and } \\
\text { REE }\end{array}$ & \\
\hline $\begin{array}{l}\text { Inclusion criteria: obese (BMI } \\
30-37 \mathrm{~kg} / \mathrm{m}^{2} \text { ), no diabetes (fasting } \\
\text { glucose } \leq 6.1 \mathrm{mmol} / \mathrm{l} \text {, } \\
\mathrm{HbA}_{1 \mathrm{c}} \leq 42 \mathrm{mmol} / \mathrm{mol}[\leq 6.0 \%] \text { ) and } \\
\text { C-peptide level } \geq 1.0 \mathrm{nmol} / \mathrm{l} \text { ) } \\
\text { Baseline characteristics: BMI } \\
35.1 \mathrm{~kg} / \mathrm{m}^{2}, \text { fasting glucose } \\
5.6 \mathrm{mmol} / 1, \mathrm{HbA} \mathrm{Ac}_{\mathrm{c}} 38 \mathrm{mmol} / \mathrm{mol} \\
{[5.6 \%] \text { ), fasting insulin } 135 \mathrm{pmol} / 1}\end{array}$ & $33(0 / 33)$ & 6 months & $200-700 \mathrm{mg} /$ day & $\begin{array}{l}\text { Moderate hypoenergetic } \\
\text { diet }+ \text { standardised } \\
\text { exercise programme } \pm \\
\text { metformin up to } \\
850 \mathrm{mg} \text { tid }\end{array}$ & $\begin{array}{l}\text { - } \downarrow \text { Fasting insulin and } \\
\text { post-meal insulin } \\
\text { secretion } \\
\cdot \uparrow \text { Fasting glucose and } \\
\text { post-meal peak glucose } \\
\cdot \text { No difference in } \mathrm{HbA}_{1 \mathrm{c}} \\
\text { levels } \\
\text { - } \uparrow \text { Insulin sensitivity } \\
\text { (HOMA-IR) } \\
\text { - } \downarrow \text { Body weight }\end{array}$ & {$[74]$} \\
\hline
\end{tabular}

${ }^{\text {a }}$ Comparisons of outcomes compared variables at the end of the intervention in diazoxide-treated participants with the placebo groups

$\mathrm{AIR}_{\mathrm{g}}$, acute insulin response to glucose; F, female; GSIS, glucose-stimulated insulin secretion; iAUC $\mathrm{C}_{\mathrm{ins}}$, incremental area under the insulin curve; $\mathrm{K}_{\mathrm{G}}$, glucose disposal rate; M, male; MTT, meal tolerance test; REE, resting energy expenditure; tid, three times a day

discrepant findings are not simple to explain. However, diazoxide did not consistently improve glucose levels, rather resulting in a small increase in blood glucose in one study [74] and deterioration in glucose tolerance in another [73], as compared with placebo. These studies in obese, non-diabetic participants would support the conclusion of the group of authors of one of these studies who stated that 'these findings do not suggest that hyperinsulinaemia per se contributes to maintenance of the obese state, and insulin secretion inhibition seems not a promising drug target.' [73].

Inhibition of insulin release with somatostatin analogues also does not support a primary role of hyperinsulinaemia in the pathogenesis of dysglycaemia. Obese individuals treated for 24 weeks with octreotide experienced weight loss that correlated with the improvement in insulin sensitivity, making it difficult to know which occurred first [75]. However, in a 1-week study in healthy 
participants, octreotide administration reduced insulin levels but did not change insulin sensitivity. Rather, it impaired beta cell function and reduced insulin-independent glucose uptake, resulting in elevated glucose levels [76].

Insulin sensitisers: metformin and thiazolidinediones Metformin treatment in individuals with IGT reduces the risk of progression to type 2 diabetes $[69,77,78]$. In the Diabetes Prevention Program, metformin improved insulin sensitivity with a weight loss of about $2 \mathrm{~kg}$ within a year. This resulted in beta cell offloading and reduced insulin responses that, in the context of improved insulin sensitivity, represented enhanced beta cell function [70, 79]. In a study of a large cohort of recently diagnosed, drug-naive type 2 diabetic individuals, 4 years of metformin treatment improved insulin sensitivity and, again, reduced secretory demand on the beta cell, leading to lower insulin responses and overall better beta cell function [80].

Thiazolidinediones, which primarily act to improve insulin sensitivity, have similar effects on insulin sensitivity, insulin responses and beta cell function as metformin, although the magnitude of the effect on insulin sensitivity is greater $[80,81]$. Thus, the reduction in beta cell secretory demand is superior. Further, these effects occur in spite of an increase in body weight. Studies of thiazolidinediones in diabetes prevention and early intervention have all demonstrated a beneficial effect of this medication class, which is also greater than that of metformin [78, 81-84].

In sum, these studies with metformin and thiazolidinediones provide valuable insight into the primary beta cell dysfunction vs primary insulin hypersecretion hypotheses. Use of these insulin sensitisers is not associated with the development of hypoglycaemia, in keeping with the notion that improvements in insulin sensitivity are associated with the appropriate downregulation of insulin output by the beta cell. If the primary lesion was insulin hypersecretion, and insulin resistance represented an adaptive response, it would have been anticipated that, in the face of the improvement in insulin sensitivity, the beta cell would inappropriately continue to secrete increased amounts of insulin so that many individuals would have experienced hypoglycaemia. Thus, we believe that these clinical data strongly support beta cell dysfunction as the primary abnormality in dysglycaemia.

Insulin secretagogues: sulfonylureas and incretin-based medications Insulin secretagogues by nature increase insulin release. In general, despite increased insulin concentrations, no change in insulin sensitivity is observed unless weight loss also occurs, as frequently observed with glucagon-like peptide-1 receptor (GLP-1R) agonist treatment. Further, over time the increased secretory demand on the beta cell results in a progressive loss of beta cell function when compared with medications that improve insulin sensitivity [80]. These longterm differences were first demonstrated with sulfonylureas [80], but more recently the dipeptidyl peptidase-4 (DPP-4) inhibitor linagliptin showed a similar rate of deterioration in glucose control as the sulfonylurea glipizide [85], suggesting this effect is not limited to one class of secretagogues or dependent on body weight. Whether the same occurs with GLP-1R agonists is unclear as there are no long-term active comparator studies with sulfonylureas.

With these three classes of secretagogues, one sees divergent effects on weight: sulfonylureas increase body weight, DPP-4 inhibitors are weight neutral and GLP-1R agonists decrease weight. Thus, the relationship between increased insulin secretion and the development of obesity/insulin resistance is not congruent, although the ability of GLP-1R agonists to reduce satiety confounds the interpretation somewhat.

In sum, the enhancement of beta cell failure with insulin secretagogues is compatible with either model of dysglycaemia development. With the primary hyperinsulinaemia hypothesis, one would have expected the development of obesity and/or insulin resistance. However, the lack of insulin resistance with both sulfonylureas and DPP-4 inhibitors, as well as the weight neutrality and lack of hypoglycaemia with the DPP-4 inhibitors, are contrary to what might have been expected with this hypothesis.

Bariatric/metabolic surgery Weight-loss surgery has also been quite informative regarding the two hypotheses. Within a week after surgery in patients with type 2 diabetes, it has been reported that insulin levels decline, insulin sensitivity improves and glucose levels fall [86]. This observation has been interpreted as hyperinsulinaemia being the primary problem in dysglycaemia since decreased insulinaemia preceded the resolution of insulin resistance [10, 12, 13, 87]. However, in this same study, the control group of obese individuals with no diabetes also demonstrated a significant reduction in fasting insulin but without a change in insulin sensitivity, even 3 months after the surgery [86]. In contrast, others have not observed an early change in insulin sensitivity following surgery [88]. In the study that made a strong case for primary hyperinsulinaemia being the primary event in the pathogenesis of dysglycaemia [86], energy intake was not reported. This would have been very informative given that the similar degrees of weight loss that were achieved 3 weeks after gastric bypass surgery or commencement of a very-low-energy diet resulted in similar reductions in fasting insulin and improvements in insulin sensitivity [89]. Finally, similarities in the outcomes from these two interventions raises the question of whether the gastrointestinal tract itself is important in the development of hyperinsulinaemia.

\section{Youths vs adults: new insights into the pathophysiology of dysglycaemia}

Similar to adults, type 2 diabetes in youths is characterised by peripheral and hepatic insulin resistance, together with beta 


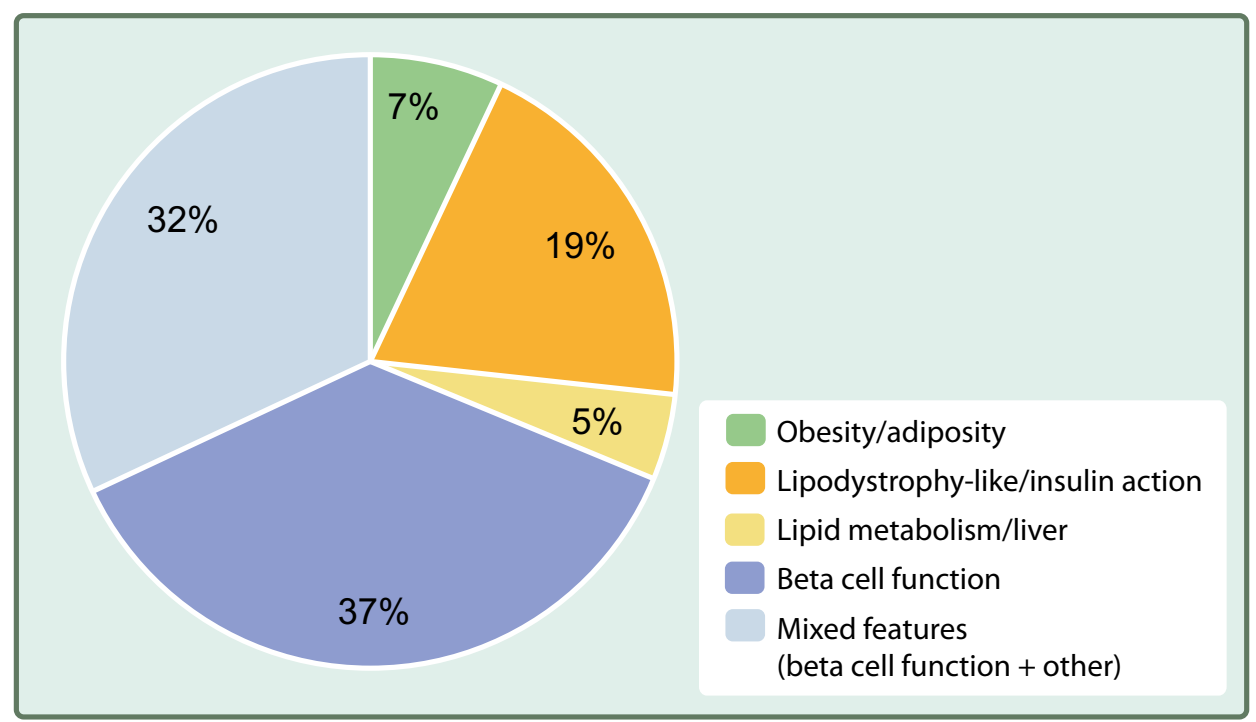

Fig. 5 Phenotypes associated with gene variants linked to type 2 diabetes. The proportions of gene variants (SNPs) associated with type 2 diabetes susceptibility, the function of which have been linked to specific phenotypic characteristics, are shown. Clinical and biochemical features define phenotypes of reduced beta cell function (beta cell and proinsulin), obesity/adiposity, lipodystrophy-like/insulin action and lipid metabolism/liver. Of over 400 variants identified by genome-wide association studies (GWAS), 128 have been linked to one or more of the phenotypes listed.

cell dysfunction that worsens over time [90-92]. The disease appears to be more aggressive in youths with higher treatment failure rates $[78,80,93,94]$. A reduction in beta cell function has also been demonstrated before the development of dysglycaemia $[95,96]$. Of note, in the EarlyBird cohort study, a longitudinal study examining trajectories of both beta cell function and insulin sensitivity in young children, reduced beta cell function was already present at 5 years of age in children who had normal fasting glucose who subsequently developed IFG during puberty [97].

The Restoring Insulin Secretion (RISE) Study has, for the first time, directly compared insulin sensitivity, beta cell function and treatment response in adults and youths with IGT or recently diagnosed type 2 diabetes [98-100]. At baseline, youths were more insulin resistant and had greater insulin responses for any degree of insulin sensitivity despite similar levels of obesity and dysglycaemia as compared with adults $[98,99]$. Further, in youths with IGT and type 2 diabetes, beta cell function progressively deteriorated while on metformin alone or insulin glargine followed by metformin [100]; this deterioration was not observed in adults.

Using the feedback loop concept of the regulation of glucose metabolism, given youths and adults had similar impairments in glucose tolerance, one would have expected insulin resistance in the youths to have been proportionately balanced by an increase in the insulin response. However, the observation of beta cell hyperresponsiveness in the younger age group at baseline suggests one of two things: (1) that there is a greater workload on beta cells in youths than adults due to the more severe insulin
If a variant had more than a single feature, it was classified as mixed $(n=$ 41 variants). Of the mixed phenotypes, all included beta cell function features. Seven genes had multiple variants in which separate variants were associated with different phenotypes. Variants linked to type 2 diabetes that did not have a distinct phenotype were considered unclassified and not included in this analysis. Figure based on data from soft clustering data analysis [103, 104]. This figure is available as part of a downloadable slideset

resistance and/or primary hyperinsulinaemia, both of which may contribute to more rapid beta cell failure; or (2) since both youths and adults had similar glucose tolerance, insulin levels in youths are disproportionately increased for the degree of insulin resistance, strongly suggesting that the increased insulin responses in youths represent compensation for something else, such as decreased insulin-independent glucose uptake (glucose-mediated glucose disposal), rather than representing primary hyperinsulinaemia. This latter hypothesis would be in line with findings from studies of normoglycaemic offspring, the parents of which both had type 2 diabetes. Offspring that developed diabetes had reduced insulin-independent glucose uptake and were more insulin resistant 10 years prior to the development of the disease, as compared with offspring that did not develop hyperglycaemia [101].

These new comparisons in youths and adults highlight that a great deal more work is needed to understand why type 2 diabetes is now emerging in youths.

\section{Areas for future work}

A better understanding of the correct pathophysiological sequence leading to type 2 diabetes will be valuable in better designing preventative and therapeutic approaches. Here we consider a limited approach to increasing our knowledge.

More longitudinal studies are needed as most opinions are based on associative studies. Large longitudinal observation cohort studies, like EarlyBird [97], could be expected to 
inform us about the natural history of the beta cell, if commenced early in life.

Genome-wide association studies (GWAS) have clearly identified more than 400 gene variants (SNPs) associated with type 2 diabetes [102]. While most gene products from these variants have not been identified, 128 of them have been linked phenotypically to beta cell dysfunction [103, 104] (Fig. 5). Recent work from the EarlyBird cohort demonstrated that genetic markers associated with type 2 diabetes in adults are also present in youths [105]. These markers were more commonly associated with beta cell dysfunction and increasing glucose, independent of BMI or insulin resistance. Similar observations were made in obese, adolescent white, Hispanic and AfricanAmerican youths followed longitudinally [106]. In these youths with five known SNPs associated with type 2 diabetes, mathematical modelling demonstrated that with increasing numbers of risk alleles there was no difference in insulin sensitivity, but early-phase insulin secretion was reduced and the risk of developing IGT and type 2 diabetes over time was increased. Whether any of these gene variants may have been associated with preceding insulin hypersecretion is unknown. Further, epigenetics also provides compelling evidence for dysregulation of isletspecific gene expression in type 2 diabetes [107, 108]. However, it is not clear whether this occurs prior to or following the development of hyperglycaemia or whether it could even be transgenerational. Longitudinal studies starting at birth would, again, be informative with regard to this, in this instance from both genetic and epigenetic perspectives.

Preclinical studies using cell lines or animal models have always been informative and should continue to be performed. Importantly, they cannot fully replace human investigations of glucose metabolism. Small animals more readily facilitate studies of gene deletion or upregulation; however, these may represent extreme phenotypes and do not necessarily translate to human physiology [51-53, 109]. In addition, as mentioned earlier when discussing the insulin gene deletion studies in mice, it is critical to include the appropriate control groups, in which no genetic modification and/or intervention have been performed.

While not perfect because all potential confounders cannot be controlled, human interventional studies are necessary. While, in our minds, the studies with diazoxide are fairly definitive, others may argue they are not ideal. Thus, it is important to test the primary hypersecretion hypothesis in humans by using an alternative intervention that directly reduces insulin secretion for a prolonged period of time, and to quantify, with formal measures, the effects on glucose metabolism, from insulin sensitivity to beta cell function, along with body weight regulation.

\section{Summary}

\section{What is the question?}

While beta cell dysfunction is the critical component responsible for the increase in glucose observed in prediabetes and type 2 diabetes, the question is whether this beta cell dysfunction is present from early in the disease course or arises late as a result of beta cell exhaustion following prolonged primary insulin hypersecretion.

\section{What is the key observation?}

Beta cell dysfunction is clearly present at the time of development of dysglycaemia (IGT/type 2 diabetes). The preponderance of the evidence supports this dysfunction being the early event in the natural history of dysglycaemia. However, the heterogeneity of type 2 diabetes suggests an outside possibility that, in some, primary hyperinsulinaemia may be an early event.

\section{Selected outstanding questions for a better understanding of the pathophysiological se- quence leading to type 2 diabetes:}

- Does primary overstimulation of the beta cell and the resulting hyperinsulinaemia precede insulin resistance and, ultimately, lead to type 2 diabetes in some individuals?

- Are some beta cell gene variants that are linked to type 2 diabetes associated with preceding insulin hypersecretion rather than decreased insulin output?

- Can an intervention aimed at directly reducing insulin secretion for a prolonged period of time prevent the development of obesity, insulin resistance and type 2 diabetes?

\section{Conclusion}

While it is clear that type 2 diabetes is a heterogeneous condition characterised by beta cell failure, whether beta cell dysfunction or primary hyperinsulinaemia is the early event in the pathogenesis of dysglycaemia is now up for debate. We believe that the weight of the evidence in humans (and animal models) supports the principal defect in most individuals as being early beta cell dysfunction associated with reduced insulin secretion, rather than primary hypersecretion. Thus, it seems incumbent on the proponents of the primary hyperinsulinaemia hypothesis to undertake further studies to make their case more forcefully. Improved understanding of whichever mechanism underlies beta cell dysfunction should allow us to provide better preventative and therapeutic interventions for type 2 diabetes. 
Acknowledgements We thank D. Porte, Jr., M. Hogan and A. Templin (University of Washington, Seattle, WA, USA) for valuable discussions during the writing of this manuscript.

Funding Work in the authors' laboratory is supported by the United States Department of Veterans Affairs (I01BX001060 to SEK), VA Puget Sound Health Care System (Seattle, WA, USA), Seattle Institute for Biomedical and Clinical Research (Seattle, WA, USA) and National Institutes of Health grant R01 DK017047. NE is supported by the Dick and Julia McAbee Endowed Postdoctoral Fellowship from the University of Washington, the French Diabetes Society, the Belgian American Educational Foundation and the Baillet-Latour Found, the Belgian Diabetes Association, the Horlait-Dapsens Foundation and the Leon Fredericq Foundation.

Authors' relationships and activities SEK has served as an advisor to Boehringer Ingelheim, Eli Lilly, Intarcia, Janssen, Merck, Novo Nordisk and Pfizer. The remaining authors declare that there are no relationships or activities that might bias, or be perceived to bias, their work.

Contribution statement NE drafted the manuscript and all authors revised it critically for important intellectual content. All authors approved the submitted version.

\section{References}

1. Kahn SE (2003) The relative contributions of insulin resistance and beta-cell dysfunction to the pathophysiology of type 2 diabetes. Diabetologia 46(1):3-19. https://doi.org/10.1007/s00125002-1009-0

2. Reaven GM (1988) Banting lecture 1988. Role of insulin resistance in human disease. Diabetes 37(12):1595-1607. https://doi. org/10.2337/diab.37.12.1595

3. Warram JH, Martin BC, Krolewski AS, Soeldner JS, Kahn CR (1990) Slow glucose removal rate and hyperinsulinemia precede the development of type II diabetes in the offspring of diabetic parents. Ann Intern Med 113(12):909-915. https://doi.org/10. 7326/0003-4819-113-12-909

4. DeFronzo RA, Ferrannini E (1991) Insulin resistance. A multifaceted syndrome responsible for NIDDM, obesity, hypertension, dyslipidemia, and atherosclerotic cardiovascular disease. Diabetes Care 14(3):173-194. https://doi.org/10.2337/diacare.14. 3.173

5. Kruszynska YT, Olefsky JM (1996) Cellular and molecular mechanisms of non-insulin dependent diabetes mellitus. J Investig Med 44(8):413-428

6. Porte D Jr (1991) Banting lecture 1990. Beta-cells in type II diabetes mellitus. Diabetes 40(2):166-180. https://doi.org/10.2337/ diab.40.2.166

7. Mitrakou A, Kelley D, Mokan M et al (1992) Role of reduced suppression of glucose production and diminished early insulin release in impaired glucose tolerance. N Engl J Med 326(1):2229. https://doi.org/10.1056/nejm199201023260104

8. Fernandez-Castaner M, Biarnes J, Camps I, Ripolles J, Gomez N, Soler J (1996) Beta-cell dysfunction in first-degree relatives of patients with non-insulin-dependent diabetes mellitus. Diabet Med 13(11):953-959. https://doi.org/10.1002/(sici)10969136(199611)13:11<953::Aid-dia257>3.0.Co;2-v

9. Shanik MH, Xu Y, Skrha J, Dankner R, Zick Y, Roth J (2008) Insulin resistance and hyperinsulinemia: is hyperinsulinemia the cart or the horse? Diabetes Care 31(Suppl 2):S262-S268. https:// doi.org/10.2337/dc08-s264

10. Pories WJ, Dohm GL (2012) Diabetes: have we got it all wrong? Hyperinsulinism as the culprit: surgery provides the evidence. Diabetes Care 35(12):2438-2442. https://doi.org/10.2337/dc120684

11. Corkey BE (2012) Banting lecture 2011. Hyperinsulinemia: cause or consequence? Diabetes 61(1):4-13. https://doi.org/10.2337/ db11-1483

12. Erion K, Corkey BE (2018) Beta-cell failure or beta-cell abuse? Front Endocrinol 9:532. https://doi.org/10.3389/fendo.2018. 00532

13. Page MM, Johnson JD (2018) Mild suppression of hyperinsulinemia to treat obesity and insulin resistance. Trends Endocrinol Metab 29(6):389-399. https://doi.org/10.1016/j.tem. 2018.03.018

14. Nolan CJ, Prentki M (2019) Insulin resistance and insulin hypersecretion in the metabolic syndrome and type 2 diabetes: time for a conceptual framework shift. Diab Vasc Dis Res 16(2):118-127. https://doi.org/10.1177/1479164119827611

15. Kahn SE, Prigeon RL, McCulloch DK et al (1993) Quantification of the relationship between insulin sensitivity and beta-cell function in human subjects. Evidence for a hyperbolic function. Diabetes 42(11):1663-1672. https://doi.org/10.2337/diab.42.11. 1663

16. Weyer C, Bogardus C, Mott DM, Pratley RE (1999) The natural history of insulin secretory dysfunction and insulin resistance in the pathogenesis of type 2 diabetes mellitus. J Clin Invest 104(6): 787-794. https://doi.org/10.1172/jci7231

17. Jensen CC, Cnop M, Hull RL, Fujimoto WY, Kahn SE (2002) Beta-cell function is a major contributor to oral glucose tolerance in high-risk relatives of four ethnic groups in the U.S. Diabetes 51(7):2170-2178. https://doi.org/10.2337/diabetes.51.7.2170

18. Festa A, Williams K, D'Agostino R Jr, Wagenknecht LE, Haffner SM (2006) The natural course of beta-cell function in nondiabetic and diabetic individuals: the Insulin Resistance Atherosclerosis Study. Diabetes 55(4):1114-1120. https://doi.org/10.2337/ diabetes.55.04.06.db05-1100

19. Utzschneider KM, Prigeon RL, Faulenbach MV et al (2009) Oral disposition index predicts the development of future diabetes above and beyond fasting and 2-h glucose levels. Diabetes Care 32(2):335-341. https://doi.org/10.2337/dc08-1478

20. Stancakova A, Javorsky M, Kuulasmaa T, Haffner SM, Kuusisto J, Laakso M (2009) Changes in insulin sensitivity and insulin release in relation to glycemia and glucose tolerance in 6,414 Finnish men. Diabetes 58(5):1212-1221. https://doi.org/10.2337/ db08-1607

21. Staimez LR, Weber MB, Ranjani H et al (2013) Evidence of reduced beta-cell function in Asian Indians with mild dysglycemia. Diabetes Care 36(9):2772-2778. https://doi.org/10. 2337/dc12-2290

22. Pimenta W, Korytkowski M, Mitrakou A et al (1995) Pancreatic beta-cell dysfunction as the primary genetic lesion in NIDDM. Evidence from studies in normal glucose-tolerant individuals with a first-degree NIDDM relative. JAMA 273(23):1855-1861. https://doi.org/10.1001/jama.1995.03520470063033

23. van Haeften TW, Dubbeldam S, Zonderland ML, Erkelens DW (1998) Insulin secretion in normal glucose-tolerant relatives of type 2 diabetic subjects. Assessments using hyperglycemic glucose clamps and oral glucose tolerance tests. Diabetes Care 21(2):278-282. https://doi.org/10.2337/diacare.21.2.278

24. Cnop M, Vidal J, Hull RL et al (2007) Progressive loss of beta-cell function leads to worsening glucose tolerance in first-degree relatives of subjects with type 2 diabetes. Diabetes Care 30(3):677682. https://doi.org/10.2337/dc06-1834 
25. Dunaif A, Finegood DT (1996) Beta-cell dysfunction independent of obesity and glucose intolerance in the polycystic ovary syndrome. J Clin Endocrinol Metab 81(3):942-947. https://doi. org/10.1210/jcem.81.3.8772555

26. Ward WK, Johnston CL, Beard JC, Benedetti TJ, Halter JB, Porte D Jr (1985) Insulin resistance and impaired insulin secretion in subjects with histories of gestational diabetes mellitus. Diabetes 34(9):861-869. https://doi.org/10.2337/diab.34.9.861

27. Xiang AH, Takayanagi M, Black MH et al (2013) Longitudinal changes in insulin sensitivity and beta cell function between women with and without a history of gestational diabetes mellitus. Diabetologia 56(12):2753-2760. https://doi.org/10.1007/s00125013-3048-0

28. Fujimoto WY, Leonetti DL, Kinyoun JL et al (1987) Prevalence of diabetes mellitus and impaired glucose tolerance among second-generation Japanese-American men. Diabetes 36(6):721729. https://doi.org/10.2337/diab.36.6.721

29. Sherry NA, Tsai EB, Herold KC (2005) Natural history of betacell function in type 1 diabetes. Diabetes 54(Suppl 2):S32-S39. https://doi.org/10.2337/diabetes.54.suppl_2.s32

30. Raffel LJ, Robbins DC, Norris JM et al (1996) The GENNID study. A resource for mapping the genes that cause NIDDM. Diabetes Care 19(8):864-872. https://doi.org/10.2337/diacare.19. 8.864

31. Ferrannini E, Gastaldelli A, Miyazaki Y, Matsuda M, Mari A, DeFronzo RA (2005) $\beta$-Cell function in subjects spanning the range from normal glucose tolerance to overt diabetes: a new analysis. J Clin Endocrinol Metab 90(1):493-500. https://doi. org/10.1210/jc.2004-1133

32. Mengozzi A, Tricò D, Nesti L et al (2020) Disruption of fasting and post-load glucose homeostasis are largely independent and sustained by distinct and early major beta-cell function defects: a cross-sectional and longitudinal analysis of the Relationship between Insulin Sensitivity and Cardiovascular risk (RISC) study cohort. Metabolism 105:154185. https://doi.org/10.1016/j. metabol.2020.154185

33. den Biggelaar LJ, Sep SJ, Eussen SJ et al (2017) Discriminatory ability of simple OGTT-based beta cell function indices for prediction of prediabetes and type 2 diabetes: the CODAM study. Diabetologia 60(3):432-441. https://doi.org/10.1007/s00125016-4165-3

34. Defronzo RA, Tripathy D, Schwenke DC et al (2013) Prediction of diabetes based on baseline metabolic characteristics in individuals at high risk. Diabetes Care 36(11):3607-3612. https://doi.org/ $10.2337 / \mathrm{dc} 13-0520$

35. Pontiroli AE, Alberetto M, Capra F, Pozza G (1990) The glucose clamp technique for the study of patients with hypoglycemia: insulin resistance as a feature of insulinoma. J Endocrinol Investig 13(3):241-245. https://doi.org/10.1007/bf03349549

36. Del Prato S, Riccio A, Vigili de Kreutzenberg S et al (1993) Mechanisms of fasting hypoglycemia and concomitant insulin resistance in insulinoma patients. Metabolism 42(1):24-29. https://doi.org/10.1016/0026-0495(93)90167-m

37. Battezzati A, Terruzzi I, Perseghin G et al (1995) Defective insulin action on protein and glucose metabolism during chronic hyperinsulinemia in subjects with benign insulinoma. Diabetes 44(7):837-844. https://doi.org/10.2337/diab.44.7.837

38. Del Prato S, Leonetti F, Simonson DC, Sheehan P, Matsuda M, DeFronzo RA (1994) Effect of sustained physiologic hyperinsulinaemia and hyperglycaemia on insulin secretion and insulin sensitivity in man. Diabetologia 37(10):1025-1035. https://doi.org/10.1007/bf00400466

39. Dankner R, Chetrit A, Shanik MH, Raz I, Roth J (2009) Basalstate hyperinsulinemia in healthy normoglycemic adults is predictive of type 2 diabetes over a 24 -year follow-up: a preliminary report. Diabetes Care 32(8):1464-1466. https://doi.org/10.2337/ dc09-0153

40. Hulman A, Simmons RK, Brunner EJ et al (2017) Trajectories of glycaemia, insulin sensitivity and insulin secretion in South Asian and white individuals before diagnosis of type 2 diabetes: a longitudinal analysis from the Whitehall II cohort study. Diabetologia 60(7):1252-1260. https://doi.org/10.1007/s00125-017-4275-6

41. Tabak AG, Jokela M, Akbaraly TN, Brunner EJ, Kivimaki M, Witte DR (2009) Trajectories of glycaemia, insulin sensitivity, and insulin secretion before diagnosis of type 2 diabetes: an analysis from the Whitehall II study. Lancet 373(9682):2215-2221. https://doi.org/10.1016/s0140-6736(09)60619-x

42. Weyer C, Hanson RL, Tataranni PA, Bogardus C, Pratley RE (2000) A high fasting plasma insulin concentration predicts type 2 diabetes independent of insulin resistance: evidence for a pathogenic role of relative hyperinsulinemia. Diabetes 49(12):2094 2101. https://doi.org/10.2337/diabetes.49.12.2094

43. Trico D, Natali A, Arslanian S, Mari A, Ferrannini E (2018) Identification, pathophysiology, and clinical implications of primary insulin hypersecretion in nondiabetic adults and adolescents. JCI Insight 3(24):e124912. https://doi.org/10.1172/jci. insight. 124912

44. Andrikopoulos S, Massa CM, Aston-Mourney K et al (2005) Differential effect of inbred mouse strain (C57BL/6, DBA/2, 129T2) on insulin secretory function in response to a high fat diet. J Endocrinol 187(1):45-53. https://doi.org/10.1677/joe.1.06333

45. Fontaine DA, Davis DB (2016) Attention to background strain is essential for metabolic research: C57BL/6 and the International Knockout Mouse Consortium. Diabetes 65(1):25-33. https://doi. org/10.2337/db15-0982

46. Hull RL, Willard JR, Struck MD et al (2017) High fat feeding unmasks variable insulin responses in male C57BL/6 mouse substrains. J Endocrinol 233(1):53-64. https://doi.org/10.1530/ JOE-16-0377

47. Hull RL, Kodama K, Utzschneider KM, Carr DB, Prigeon RL, Kahn SE (2005) Dietary-fat-induced obesity in mice results in beta cell hyperplasia but not increased insulin release: evidence for specificity of impaired beta cell adaptation. Diabetologia 48(7): 1350-1358. https://doi.org/10.1007/s00125-005-1772-9

48. Surwit RS, Kuhn CM, Cochrane C, McCubbin JA, Feinglos MN (1988) Diet-induced type II diabetes in C57BL/6J mice. Diabetes 37(9):1163-1167. https://doi.org/10.2337/diab.37.9.1163

49. Parilla JH, Willard JR, Barrow BM, Zraika S (2018) A mouse model of beta-cell dysfunction as seen in human type 2 diabetes. J Diabetes Res 2018:6106051. https://doi.org/10.1155/2018/ 6106051

50. Kahn CR, Bruning JC, Michael MD, Kulkarni RN (2000) Knockout mice challenge our concepts of glucose homeostasis and the pathogenesis of diabetes mellitus. J Pediatr Endocrinol Metab 13(Suppl 6):1377-1384. https://doi.org/10.1515/jpem2000-s611

51. Rossetti L, Stenbit AE, Chen W et al (1997) Peripheral but not hepatic insulin resistance in mice with one disrupted allele of the glucose transporter type 4 (GLUT4) gene. J Clin Invest 100(7): 1831-1839. https://doi.org/10.1172/jci119711

52. Bruning JC, Michael MD, Winnay JN et al (1998) A musclespecific insulin receptor knockout exhibits features of the metabolic syndrome of NIDDM without altering glucose tolerance. Mol Cell 2(5):559-569. https://doi.org/10.1016/s1097-2765(00) 80155-0

53. Michael MD, Kulkarni RN, Postic C et al (2000) Loss of insulin signaling in hepatocytes leads to severe insulin resistance and progressive hepatic dysfunction. Mol Cell 6(1):87-97. https:// doi.org/10.1016/S1097-2765(05)00015-8

54. Bruning JC, Gautam D, Burks DJ et al (2000) Role of brain insulin receptor in control of body weight and reproduction. Science 
289(5487):2122-2125. https://doi.org/10.1126/science.289.5487. 2122

55. Kulkarni RN, Bruning JC, Winnay JN, Postic C, Magnuson MA, Kahn CR (1999) Tissue-specific knockout of the insulin receptor in pancreatic beta cells creates an insulin secretory defect similar to that in type 2 diabetes. Cell 96(3):329-339. https://doi.org/10. 1016/s0092-8674(00)80546-2

56. Larue-Achagiotis C, Goubern M, Laury MC (1988) Concomitant food intake and adipose tissue responses under chronic insulin infusion in rats. Physiol Behav 44(1):95-100. https://doi.org/10. 1016/0031-9384(88)90351-4

57. Destefano MB, Stern JS, Castonguay TW (1991) Effect of chronic insulin administration on food intake and body weight in rats. Physiol Behav 50(4):801-806. https://doi.org/10.1016/00319384(91)90021-f

58. Juan CC, Fang VS, Kwok CF, Perng JC, Chou YC, Ho LT (1999) Exogenous hyperinsulinemia causes insulin resistance, hyperendothelinemia, and subsequent hypertension in rats. Metabolism 48(4):465-471. https://doi.org/10.1016/s00260495(99)90105-1

59. Templeman NM, Clee SM, Johnson JD (2015) Suppression of hyperinsulinaemia in growing female mice provides long-term protection against obesity. Diabetologia 58(10):2392-2402. https://doi.org/10.1007/s00125-015-3676-7

60. Templeman NM, Mehran AE, Johnson JD (2016) Hypervariability in circulating insulin, high fat feeding outcomes, and effects of reducing Ins2 dosage in male Ins1-null mice in a specific pathogen-free facility. PLoS One 11(4):e0153280. https://doi. org/10.1371/journal.pone. 0153280

61. Mehran AE, Templeman NM, Brigidi GS et al (2012) Hyperinsulinemia drives diet-induced obesity independently of brain insulin production. Cell Metab 16(6):723-737. https://doi. org/10.1016/j.cmet.2012.10.019

62. Leroux L, Desbois P, Lamotte L et al (2001) Compensatory responses in mice carrying a null mutation for Ins1 or Ins2. Diabetes 50(Suppl 1):S150-S153. https://doi.org/10.2337/ diabetes.50.2007.s150

63. Sonnenberg GE, Kemmer FW, Berger M (1990) Exercise in type 1 (insulin-dependent) diabetic patients treated with continuous subcutaneous insulin infusion. Prevention of exercise induced hypoglycaemia. Diabetologia 33(11):696-703. https://doi.org/10. 1007/bf00400572

64. Tsalikian E, Kollman C, Tamborlane WB et al (2006) Prevention of hypoglycemia during exercise in children with type 1 diabetes by suspending basal insulin. Diabetes Care 29(10):2200-2204. https://doi.org/10.2337/dc06-0495

65. Zhong VW, Crandell JL, Shay CM et al (2017) Dietary intake and risk of non-severe hypoglycemia in adolescents with type 1 diabetes. J Diabetes Complicat 31(8):1340-1347. https://doi.org/10. 1016/j.jdiacomp.2017.04.017

66. Salti I, Bénard E, Detournay B et al (2004) A population-based study of diabetes and its characteristics during the fasting month of Ramadan in 13 countries: results of the epidemiology of diabetes and Ramadan 1422/2001 (EPIDIAR) study. Diabetes Care 27(10):2306-2311. https://doi.org/10.2337/diacare.27.10.2306

67. Pan XR, Li GW, Hu YH et al (1997) Effects of diet and exercise in preventing NIDDM in people with impaired glucose tolerance. The Da Qing IGT and Diabetes Study. Diabetes Care 20(4): 537-544. https://doi.org/10.2337/diacare.20.4.537

68. Tuomilehto J, Lindstrom J, Eriksson JG et al (2001) Prevention of type 2 diabetes mellitus by changes in lifestyle among subjects with impaired glucose tolerance. N Engl J Med 344(18):13431350. https://doi.org/10.1056/nejm200105033441801

69. Knowler WC, Barrett-Connor E, Fowler SE et al (2002) Reduction in the incidence of type 2 diabetes with lifestyle intervention or metformin. N Engl J Med 346(6):393-403. https://doi.org/10.1056/NEJMoa012512

70. Kitabchi AE, Temprosa M, Knowler WC et al (2005) Role of insulin secretion and sensitivity in the evolution of type 2 diabetes in the diabetes prevention program: effects of lifestyle intervention and metformin. Diabetes 54(8):2404-2414. https://doi.org/10. 2337/diabetes.54.8.2404

71. Uusitupa M, Lindi V, Louheranta A, Salopuro T, Lindstrom J, Tuomilehto J (2003) Long-term improvement in insulin sensitivity by changing lifestyles of people with impaired glucose tolerance: 4-year results from the Finnish Diabetes Prevention Study. Diabetes 52(10):2532-2538. https://doi.org/10.2337/diabetes.52. 10.2532

72. Alemzadeh R, Langley G, Upchurch L, Smith P, Slonim AE (1998) Beneficial effect of diazoxide in obese hyperinsulinemic adults. J Clin Endocrinol Metab 83(6):1911-1915. https://doi.org/ 10.1210/jcem.83.6.4852

73. Due A, Flint A, Eriksen G et al (2007) No effect of inhibition of insulin secretion by diazoxide on weight loss in hyperinsulinaemic obese subjects during an 8-week weight-loss diet. Diabetes Obes Metab 9(4):566-574. https://doi.org/10.1111/j.1463-1326.2006. 00645.x

74. Loves S, van Groningen L, Filius M et al (2018) Effects of diazoxide-mediated insulin suppression on glucose and lipid metabolism in nondiabetic obese men. J Clin Endocrinol Metab 103(6):2346-2353. https://doi.org/10.1210/jc.2018-00161

75. Velasquez-Mieyer PA, Cowan PA, Arheart KL et al (2003) Suppression of insulin secretion is associated with weight loss and altered macronutrient intake and preference in a subset of obese adults. Int J Obes Relat Metab Disord 27(2):219-226. https://doi.org/10.1038/sj.ijo.802227

76. Kahn SE, Klaff LJ, Schwartz MW et al (1990) Treatment with a somatostatin analog decreases pancreatic B-cell and whole body sensitivity to glucose. J Clin Endocrinol Metab 71(4):994-1002. https://doi.org/10.1210/jcem-71-4-994

77. Ramachandran A, Snehalatha C, Mary S, Mukesh B, Bhaskar AD, Vijay V (2006) The Indian Diabetes Prevention Programme shows that lifestyle modification and metformin prevent type 2 diabetes in Asian Indian subjects with impaired glucose tolerance (IDPP-1). Diabetologia 49(2):289-297. https://doi.org/10.1007/ s00125-005-0097-z

78. Kahn SE, Haffner SM, Heise MA et al (2006) Glycemic durability of rosiglitazone, metformin, or glyburide monotherapy. N Engl J Med 355(23):2427-2443. https://doi.org/10.1056/ NEJMoa066224

79. Lachin JM, Christophi CA, Edelstein SL et al (2007) Factors associated with diabetes onset during metformin versus placebo therapy in the diabetes prevention program. Diabetes 56(4):11531159. https://doi.org/10.2337/db06-0918

80. Kahn SE, Lachin JM, Zinman B et al (2011) Effects of rosiglitazone, glyburide, and metformin on beta-cell function and insulin sensitivity in ADOPT. Diabetes 60(5):1552-1560. https://doi.org/10.2337/db10-1392

81. Knowler WC, Hamman RF, Edelstein SL et al (2005) Prevention of type 2 diabetes with troglitazone in the Diabetes Prevention Program. Diabetes 54(4):1150-1156. https://doi.org/10.2337/ diabetes.54.4.1150

82. Gerstein HC, Yusuf S, Bosch J et al (2006) Effect of rosiglitazone on the frequency of diabetes in patients with impaired glucose tolerance or impaired fasting glucose: a randomised controlled trial. Lancet 368(9541):1096-1105. https://doi.org/10.1016/ s0140-6736(06)69420-8

83. DeFronzo RA, Tripathy D, Schwenke DC et al (2011) Pioglitazone for diabetes prevention in impaired glucose tolerance. N Engl J Med 364(12):1104-1115. https://doi.org/10. 1056/NEJMoa1010949 
84. Buchanan TA, Xiang AH, Peters RK et al (2002) Preservation of pancreatic beta-cell function and prevention of type 2 diabetes by pharmacological treatment of insulin resistance in high-risk hispanic women. Diabetes 51(9):2796-2803. https://doi.org/10. 2337/diabetes.51.9.2796

85. Rosenstock J, Kahn SE, Johansen OE et al (2019) Effect of linagliptin vs glimepiride on major adverse cardiovascular outcomes in patients with type 2 diabetes: the CAROLINA randomized clinical trial. JAMA 322(12):1155-1166. https://doi. org/10.1001/jama.2019.13772

86. Reed MA, Pories WJ, Chapman W et al (2011) Roux-en-Y gastric bypass corrects hyperinsulinemia implications for the remission of type 2 diabetes. J Clin Endocrinol Metab 96(8):2525-2531. https://doi.org/10.1210/jc.2011-0165

87. Corkey BE (2012) Diabetes: have we got it all wrong? Insulin hypersecretion and food additives: cause of obesity and diabetes? Diabetes Care 35(12):2432-2437. https://doi.org/10.2337/dc120825

88. Camastra S, Gastaldelli A, Mari A et al (2011) Early and longer term effects of gastric bypass surgery on tissue-specific insulin sensitivity and beta cell function in morbidly obese patients with and without type 2 diabetes. Diabetologia 54(8):2093-2102. https://doi.org/10.1007/s00125-011-2193-6

89. Jackness C, Karmally W, Febres G et al (2013) Very low-calorie diet mimics the early beneficial effect of Roux-en-Y gastric bypass on insulin sensitivity and beta-cell function in type 2 diabetic patients. Diabetes 62(9):3027-3032. https://doi.org/10.2337/ db12-1762

90. Bacha F, Gungor N, Lee S, Arslanian SA (2013) Progressive deterioration of beta-cell function in obese youth with type 2 diabetes. Pediatr Diabetes 14(2):106-111. https://doi.org/10. 1111/j.1399-5448.2012.00915.x

91. Gungor N, Bacha F, Saad R, Janosky J, Arslanian S (2005) Youth type 2 diabetes: insulin resistance, beta-cell failure, or both? Diabetes Care 28(3):638-644. https://doi.org/10.2337/diacare.28. 3.638

92. Michaliszyn SF, Mari A, Lee S et al (2014) Beta-cell function, incretin effect, and incretin hormones in obese youth along the span of glucose tolerance from normal to prediabetes to type 2 diabetes. Diabetes 63(11):3846-3855. https://doi.org/10.2337/ db13-1951

93. Zeitler P, Hirst K, Pyle L et al (2012) A clinical trial to maintain glycemic control in youth with type 2 diabetes. N Engl J Med 366(24):2247-2256. https://doi.org/10.1056/NEJMoa1 109333

94. TODAY Study Group (2013) Effects of metformin, metformin plus rosiglitazone, and metformin plus lifestyle on insulin sensitivity and beta-cell function in TODAY. Diabetes Care 36(6): 1749-1757. https://doi.org/10.2337/dc12-2393

95. Tfayli H, Lee S, Arslanian S (2010) Declining beta-cell function relative to insulin sensitivity with increasing fasting glucose levels in the nondiabetic range in children. Diabetes Care 33(9):2024 2030. https://doi.org/10.2337/dc09-2292

96. Giannini C, Weiss R, Cali A et al (2012) Evidence for early defects in insulin sensitivity and secretion before the onset of glucose dysregulation in obese youths: a longitudinal study. Diabetes 61(3):606-614. https://doi.org/10.2337/db11-1111

97. Hosking J, Metcalf BS, Jeffery AN, Streeter AJ, Voss LD, Wilkin TJ (2013) Evidence of early beta-cell deficiency among children who show impaired fasting glucose: 10-yr cohort study (EarlyBird 56). Pediatr Diabetes 14(7):481-489. https://doi.org/10.1111/ pedi.12049
98. The RISE Consortium (2018) Metabolic contrasts between youth and adults with impaired glucose tolerance or recently diagnosed type 2 diabetes: I. Observations using the hyperglycemic clamp. Diabetes Care 41(8):1696-1706. https://doi.org/10.2337/dc180244

99. The RISE Consortium (2018) Metabolic contrasts between youth and adults with impaired glucose tolerance or recently diagnosed type 2 diabetes: II. Observations using the oral glucose tolerance test. Diabetes Care 41(8):1707-1716. https://doi.org/10.2337/ dc18-0243

100. The RISE Consortium (2019) Effects of treatment of impaired glucose tolerance or recently diagnosed type 2 diabetes with metformin alone or in combination with insulin glargine on $\beta$ cell function: comparison of responses in youth and adults. Diabetes 68(8):1670-1680. https://doi.org/10.2337/db19-0299

101. Martin BC, Warram JH, Krolewski AS, Bergman RN, Soeldner JS, Kahn CR (1992) Role of glucose and insulin resistance in development of type 2 diabetes mellitus: results of a 25 -year follow-up study. Lancet 340(8825):925-929. https://doi.org/10. 1016/0140-6736(92)92814-v

102. Mahajan A, Taliun D, Thurner M et al (2018) Fine-mapping type 2 diabetes loci to single-variant resolution using high-density imputation and islet-specific epigenome maps. Nat Genet 50(11):1505-1513. https://doi.org/10.1038/s41588-018-0241-6

103. Udler MS, Kim J, von Grotthuss M et al (2018) Type 2 diabetes genetic loci informed by multi-trait associations point to disease mechanisms and subtypes: a soft clustering analysis. PLoS Med 15(9):e1002654. https://doi.org/10.1371/journal.pmed.1002654

104. Mahajan A, Wessel J, Willems SM et al (2018) Refining the accuracy of validated target identification through coding variant finemapping in type 2 diabetes. Nat Genet 50(4):559-571. https://doi. org/10.1038/s41588-018-0084-1

105. Carayol J, Hosking J, Pinkney J et al (2020) Genetic susceptibility determines beta-cell function and fasting glycemia trajectories throughout childhood: a 12-year cohort study (EarlyBird 76). Diabetes Care 43(3):653-660. https://doi.org/10.2337/dc19-0806

106. Giannini C, Dalla Man C, Groop L et al (2014) Co-occurrence of risk alleles in or near genes modulating insulin secretion predisposes obese youth to prediabetes. Diabetes Care 37(2):475-482. https://doi.org/10.2337/dc13-1458

107. Ling C, Ronn T (2019) Epigenetics in human obesity and type 2 diabetes. Cell Metab 29(5):1028-1044. https://doi.org/10.1016/j. cmet.2019.03.009

108. van Dijk SJ, Tellam RL, Morrison JL, Muhlhausler BS, Molloy PL (2015) Recent developments on the role of epigenetics in obesity and metabolic disease. Clin Epigenetics 7:66. https://doi. org/10.1186/s13148-015-0101-5

109. Attané C, Peyot ML, Lussier R et al (2016) A beta cell ATGLlipolysis/adipose tissue axis controls energy homeostasis and body weight via insulin secretion in mice. Diabetologia 59(12):26542663. https://doi.org/10.1007/s00125-016-4105-2

110. Levy JC, Matthews DR, Hermans MP (1998) Correct homeostasis model assessment (HOMA) evaluation uses the computer program. Diabetes Care 21(12):2191-2192. https://doi.org/10. 2337/diacare.21.12.2191

Publisher's note Springer Nature remains neutral with regard to jurisdictional claims in published maps and institutional affiliations. 